NOTE

\title{
Interference competition among two intertidal seaweeds: Chondrus crispus strongly affects survival of Fucus evanescens recruits
}

\author{
Boris Worm ${ }^{1, *}$, Anthony R. O. Chapman ${ }^{2}$ \\ 'Institut für Meereskunde, Düsternbrooker Weg 20, D-24105 Kiel, Germany
}

\begin{abstract}
Effects of Chondrus crispus on recruitment of Fucus were examined in order to test the proposition that this red turfing alga is able to exclude fucoids from the low zone of wave-exposed shores in Nova Scotia, Canada. F. evanescens zygotes were released on experimental plots where Chondrus presence was manipulated. Grazers were excluded and not treated as an experimental factor Initial settlement density of $F$. evanescens was enhanced by presence of crustose holdfasts and canopy of Chondrus, and reduced on sandblasted bare rock. However, subsequent survival and growth of fucold germlings were heavily suppressed when Chondrus was present. A fucoid canopy established only on bare rock.
\end{abstract}

KEY WORDS: Chondrus crispus . Fucus evanescens - Interference competition Recruitment.Rocky shore-Zonation

On exposed and semi-exposed rocky shores of Nova Scotia, Canada, the low intertidal zone is dominated by the red alga Chondrus crispus (hereinafter 'Chondrus'). In contrast, the mid shore is covered by a canopy of large fucoid algae. The contention that physical factors restrict Fucus to the mid shore was discarded by Lubchenco (1980). She demonstrated that presence of the Chondrus canopy as well as the presence of the crustose holdfasts of Chondrus prevent $F$. evanescens and $F$. vesiculosus from colonizing. The mechanism by which this inhibition was effected was not clear

Although previous evidence suggests that Chondrus is competitively dominant to fucoid algae on the lower shore (Lubchenco 1980), additional studies indicate that blue mussels Mytilus edulis are top competitors at this level of the intertidal gradient (Lubchenco \& Menge 1978). Populations of this bivalve are kept in check on New England shores through intense preda-

\footnotetext{
•E-mail: bworm@ifm.uni-kiel.de
}

tion by carnivorous starfish and whelks, allowing Chondrus to flourish. When wave action is so strong that predator feeding activity is reduced, mussels replace red algal turf on the low shore.

Chondrus appears to be restricted to the low shore by physiological constraints. Reduced desiccation tolerance is correlated with the limited accurrence of this species at mid shore levels (Mathieson \& Burns 1971 , Green 1983). During winter, desiccation is less of a problem, but freezing tolerance is also correlated with position on shore (Dudgeon et al. 1989, 1990). Freezing damage in Chondrus ruptures cell membranes and reduces photosynthetic rate. Both freezing and desiccation cause cellular dehydration. which is therefore a problem for Chondrus in both summer and winter.

In addition to physiological stress, competition and carnivory, grazing can be a major structuring force in the vegetation of NW Atlantic intertidal shores. Because of the strong potential for interactive effects between grazing and competition, it is unwise to ignore confounding influences of herbivory when studying interactions between seaweed species. Grazing by the snail Littorina littorea was shown to affect the abundance of Fucus recruiting after removal of Chrondus (Lubchenco 1980). However, in these experiments the effects of grazers were incompletely controlled, as treatments without grazers were set up at an exposed site, where L. littorea was absent, but other mesograzers that feed on Fucus, such as the snail Lacuna vincta (Thomas \& Page 1983) and probably gammarid amphipods (Parker et al. 1993), were present. We tested for competitive effects of Chondrus on Fucus recruitment in the absence of grazers $\geq 1 \mathrm{~mm}$. This is necessary to avoid confounding competitive effects with effects of grazers which may be associated with Chondrus (apparent competition; Connell 1990). We hypothesized that attachment of Fucus zygotes may be 
low on the smooth crustose holdfasts of Chondrus which cover a large portion of primary space $(65 \pm 3 \%$ cover, mean $\pm 1 \mathrm{SE}, \mathrm{n}=25$ ). Furthermore we strongly suspected that growth of microrecruits might be limited by low light levels under the dense Chondrus canopy $(93 \pm 1.78 \%$ cover, $n=5)$.

Materials and methods. The experimental site was at Nowland's Point, Lower Prospect $\left(44^{\circ} 27^{\prime} \mathrm{N}\right.$, $\left.63^{\circ} 43^{\prime} \mathrm{W}\right\}, 30 \mathrm{~km}$ SW of Halifax, Nova Scotia. This semi-exposed granitic headland is largely undisturbed by human activity. The maximum tidal range in this area is $2.1 \mathrm{~m}$. Vertical distribution of dominant space occupants was quantified at 3 replicate locations on this headland. At each location, eleven $4.5 \mathrm{~m}$ transects (spaced $0.5 \mathrm{~m}$ apart) were run across the shore gradient from 0.0 to $1.1 \mathrm{~m}$ above LAT (lowest astronomical tide level). At $10 \mathrm{~cm}$ intervals, we recorded the species crossed by the transect line. Percent cover of each species at each $10 \mathrm{~cm}$ interval was calculated by dividing intercepts by number of transects and multiplying by 100 .

To test for effects of Chondrus on Fucus recruitment, 2 sub-experiments were conducted. Both subexperiments were replicated in one randomized block design $(n=6)$. To ensure uniform initial propagule densities, we seeded experimental plots $(15 \times 1.5 \mathrm{~cm})$ with zygotes from fertile Fucus evanescens plants for $24 \mathrm{~h}$. Zygote release was induced by keeping plants out of water in the dark at $10^{\circ} \mathrm{C}$ for $2 \mathrm{~d}$ prior to seeding. Pre-treated fertile plants were loosely packed into cages that were permanently installed onto all experimental plots. Cages measured $15 \times 15 \times 10 \mathrm{~cm}$ and were made from an aluminum angle frame fastened to the rock with 4 wedge anchors (Parker et al. 1993). Cages were covered with $1 \mathrm{~mm}$ nylon mesh and sealed tightly against the rock with a foam gasket. This allowed exclusion even of smaller amphipod species (Hyale nilsonii, Amphithoe rubricata) and juvenile snails $\geq 1 \mathrm{~mm}$ size (Littorina littorea, L. obtusata). Grazers were cleared manually from all plots and checked every 1 to 2 wk.

In the first sub-experiment, Chondrus presence had 2 levels: (I) Chondrus canopy removed and crustose holdfast present, (II) Chondrus canopy and crust absent (sandblasted bare rock). A second sandblasted treatment was not treated with fertile Fucus evanescens. This allowed us to compare seeded sandblasted treatments with natural recruitment levels on bare rock. Seeding was done on May 15-16, 1995. After 9 d, all plots were observed in situ, using a dissecting microscope. Within a $10 \times 10 \mathrm{~cm}$ grid, eight $1 \mathrm{~cm}^{2}$ subsamples were selected by deriving coordinates from random number tables, and attached zygotes were counted. Two blocks were not sampled quantitatively because fouling by pilayella littoralis and benthic diatoms reduced visibility of zygotes. Heavy fouling by the brown ephemeral alga Chordaria flagelliformis occurred in most cages in June. This was never observed outside cages. This canopy was removed with scissors, leaving the substratum undisturbed. F. evanescens juveniles grew rapidly and visible stages $(>1 \mathrm{~mm}$ ) in eight $1 \mathrm{~cm}^{2}$ subsamples per plot were counted on August 10, 1995. Finally, all plots were sampled destructively by scraping a $10 \times 10 \mathrm{~cm}$ area with razor blades on September 25-26, 1995. All F. evanescens $>1 \mathrm{~mm}$ were collected and counted.

In the second sub-experiment, Chondrus canopy was seeded on May 15, 1995, and also on October 13, using new plots. Because zygote density could not be examined in situ under the Chondrus canopy, it was necessary to cut randomly placed rock segments (ca $6 \times 3 \mathrm{~cm}$ ) from within treatment plots with a gasoline-powered diamond saw. To check for natural recruitment under Chondrus canopy, control rock segments were cut $1 \mathrm{~m}$ away from blocks, on the same level of shore. Cut rock segments were cemented to tiles and held for $5 \mathrm{~d}$ under a seawater sprinkler. Exposure to strong fluorescent light intensified $F$. evanescens zygote pigmentation and helped with identification on the very heterogeneous substratum. On each rock segment, a central $4 \times 2 \mathrm{~cm}$ area was examined after cutting away the Chondrus canopy. Zygotes were categorized according to the substratum to which they were attached. Sampling was done 10 d after seeding, on May 26, 1995, and after 4 mo, on September 26, 1995. Plots seeded in October were sampled after $10 \mathrm{~d}$ on October 24.

Results for the first sub-experiment were analysed by 1 -way ANOVA for each sampling date separately. Chondrus canopy treatments were analysed by 2 -way ANOVA with 'seeding' and 'month' (seeding in May and October) as experimental factors. The dependent variable was mean number of fucoid germlings. Data were log-transformed and homogeneity of variances was tested by Cochran's procedure

Results. The vertical distribution of species at the experimental site (Fig. 1) follows the general zonation pattern for Nova Srotia and New England (Stephenson \& Stephenson 1972, Lubchenco 1980). Fucus evanescens inhabits the lowest part of the Fucus belt but is largely absent from the Chondrus zone. Scattered individuals of a broad leafy form of $F$. evanescens appeared only in the lowest intertidal region, where Chondrus abundance decreased and Corallina officinalis cover increased.

Chondrus initially facilitated Fucus evanescens zygote settlement, but inhibited Fucus recruitment to visible stages (Fig. 2). Densities of $9 \mathrm{~d}$ old microrecruits were highest in the presence of Chondrus crust, relatively low on sandblasted rock and lowest on unseeded 


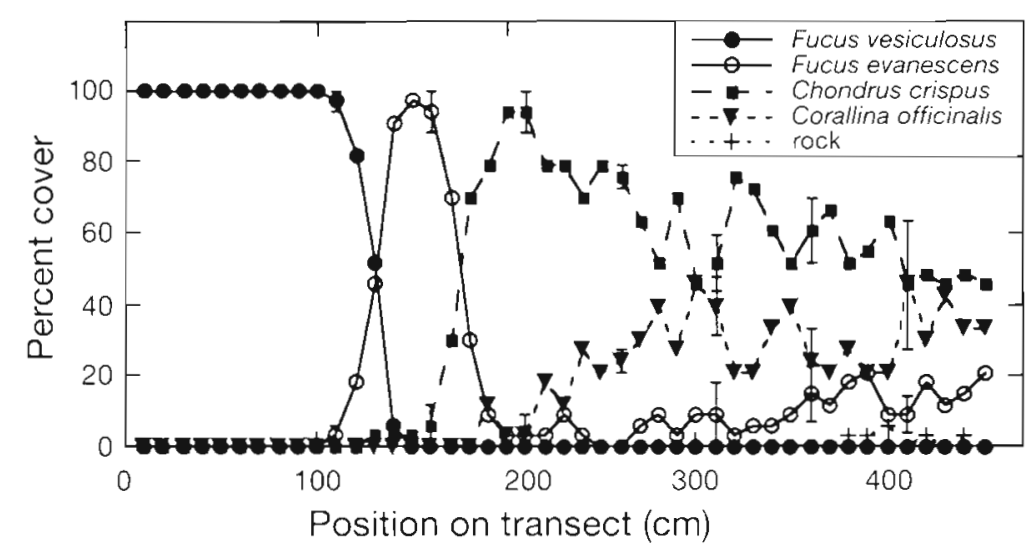

Fig. 1 Vertical zonation of dominant space occupants in the lower intertidal region. Points represent mean percent cover at $10 \mathrm{~cm}$ intervals $( \pm 1 \mathrm{SE}, \mathrm{n}=3$, shown for $50 \mathrm{~cm}$ intervals) along 33 transect lines. $0 \mathrm{~cm}$ is equivalent to $1.1 \mathrm{~m}$ above LAT, $450 \mathrm{~cm}$ to $0.0 \mathrm{~m}$ above LAT Fucus is largely absent from the Chondrus cripus zone. Corallina officinalis replaces $C$. crispus near the subtidal boundary

rock (1-way ANOVA; $\mathrm{MS}_{\text {error }}=0.11, F_{2.9}=16.4, \mathrm{p}<$ 0.001 ). Settlement under Chondrus canopy was also high and increased by experimental seeding in May and October (2-way ANOVA, $\mathrm{MS}_{\text {error }}=0.35$; factor 'seeding' $F_{1,20}=7.0, \mathrm{p}<0.05$, factor 'month' $F_{1,20}=0.02$, $n s$, 'seeding $\times$ month' $F_{1,20}=0.07$, ns). However, subsequent growth of $F$. evanescens to visible stages $>1 \mathrm{~mm}$ was drastically depressed in the presence of Chondrus crust and canopy. In plots with Chondrus crust present, densities decreased exponentially, and only $0.5 \%$ $( \pm 0.4 \% \mathrm{SE}, \mathrm{n}=5)$ of recruits in May were present as visible stages by the end of September. In the presence of Chondrus canopy, only $0.15 \%$ $( \pm 0.15 \% \mathrm{SE}, n=5)$ of $F$. evanescens recruits grew to visible size. However, some zygotes may have remained under the canopy, where they were inhibited by shading. In September, F. evanescens zygote density in canopy treatment plots was only $3.9 \%( \pm 2.4 \% \mathrm{SE}, n=6)$ of the density found in May. Clearly, not only growth, but survival of $F$. evanescens recruits is low in the presence of Chondrus. On sandblasted plots recruit densities remained stable and were significantly higher than in other treatments in August (1-way ANOVA, $\mathrm{MS}_{\text {error }}=0.039, F_{2,8}=$ 8.0, p < 0.05) and October (1-way ANOVA, $M_{\text {error }}=0.302, F_{2,8}=13.45, \mathrm{p}<$ 0.01 ). Only in the absence of Chondrus was a fucoid canopy $(3$ to $5 \mathrm{~cm}$ high, 4 plants $\mathrm{cm}^{-2}$ ) present after $4 \mathrm{mo}$.

Proportional recruit densities on the different substrata present under Chondrus canopy were measured on 24 rock segments cut from canopy treatment and control plots in May and October (Fig. 3). There was direct fucoid recruitment on Chondrus crust, but in much lower proportion $(11 \% \pm 2.4 \% \mathrm{SE}, \mathrm{n}=24)$ than expected by total cover of this substratum $(65 \% \pm 3 \% \mathrm{SE}, \mathrm{n}=25)$. Highest recruit densities occurred on unstable calcareous debris. Experimental procedures (cutting canopy perimeter to install cages, regular controls for grazers) may have reduced debris under the canopy: in unseeded controls $>50 \%$ of zygotes were attached to debris, while in seeded plots only $16 \%$ of zygotes were found on debris. This difference was significant (2-way ANOVA, angular transformation, $\mathrm{MS}_{\text {error }}=0.087$ factor 'seeding' $F_{1,20}=18.8, p<0.001$ factor 'month' $F_{1.20}=6.2, \mathrm{p}<0.05$, 'seeding $\times$ month' $F_{1.20}=0.0035$, ns). Conversely, a higher proportion of zygotes settled on rock in seeded plots compared to controls $\left(\mathrm{MS}_{\text {error }}=0.097\right.$, factor 'seeding' $F_{1,20}=7.2, p<0.05$, factor 'month' $F_{1,20}=21.4, p<0.001$, 'seeding $\times$ month' $F_{1,20}=4.45$, $\mathrm{p}<0.05)$.

Discussion. There are strong competitive effects of Chondrus on early life stages of Fucus evanescens. Chondrus dominance on the low shore in Nova Scotia may be partly explained by recruitment inhibition of mid-shore fucoids. If released from competition (and grazing) $F$. evanescens grew quickly and formed a dense canopy after 4 mo.
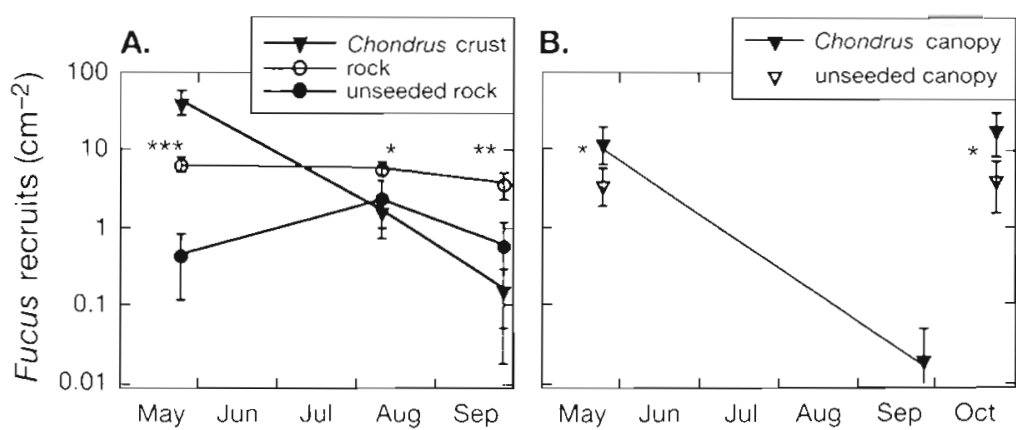

Fig. 2. Effects of Chondrus crispus presence on recruitment of Fucus evanescens. F evanescens zygotes were released from fertile plants ('seeding') on $15 \times 15 \mathrm{~cm}$ plots. Two sub-experiments were conducted: (A) Chondrus canopy was cut and the crustose holdiasts left or removed (sandblasted rock). Plots with unseeded rock controlled for natural recruitment; (B) Chondrus canopy was left intact and seeded in May and October Unseeded plots controlled for natural recruitment below Chondrus canopy. Figures for May show mean zygote densities $( \pm 1 \mathrm{SE}, \mathrm{n}=4$ ). In August and September only visible stages $>1 \mathrm{~mm}$ were counted $(n=5)$. For canopy treatments, zygote densities in a second experiment in October ( $n=6)$ are included. Significance of differences, tested by 1 -way ANOVAs, is indicated by asterisks, with $p<0.05, \cdots p<0.01, \cdots p<0.001$ 


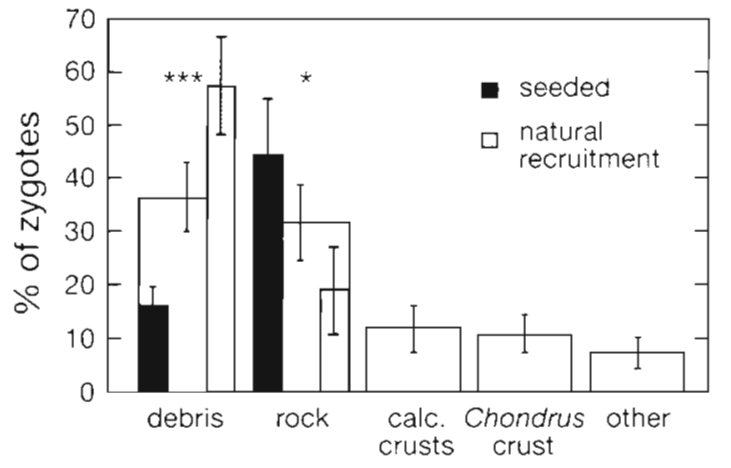

Fig. 3. Attachment of Fucus evanescens zygotes on different substrata present under Chondrus crispus turf. Open bars represent mean ( $\pm 1 \mathrm{SE}, \mathrm{n}=24$ ) proportion of zygotes on a substratum relative to total number of zygotes on rock segments cut from the Chondrus zone. Debris refers to abundant calcareous debris, trapped under the dense Chondrus turf. Calc. crusts $=$ Phymatolithon spp. There were significant effects of experimental seeding (shown by black bars) on relative zygote densities or debris, but not on the other substrata. Significance of differences is indicated as in Fig. 2

Initially, microrecruit densities were highest on plots with Chondrus crust (or canopy) present, probably due to favorable physical conditions, i.e. increased substrate heterogeneity and lower desiccation, compared with sandblasted plots. Brawley \& Johnson (1991) showed that mortality of fucoid microrecruits $(<1 \mathrm{wk}$ old) is high, and short-term survival is increased under red algal turf compared to rock. Thus, in our experiment, initial age-specific mortality may have been highest on exposed rock (Chondrus absent). At the first census date (after $9 \mathrm{~d}$ ), germlings may have passed the most susceptible stage and densities remained stable thereafter

Settlement of Cystoseira spp. under red algal turf is elevated compared to calcareous crusts (BenedettiCecchi \& Cinelli 1992). However, post-settlement fucoid recruit mortality under the turf reversed the expected pattern of Cystoseira abundance. We observed the same process. Under Chondrus canopy $>95 \%$ of $z y-$ gotes were lost after $4 \mathrm{mo}$, and $\ll 1 \%$ grew to visible size. When only Chondrus crust was present $4 \%$ of zygotes grew to visible size after $2 \mathrm{mo}$, but only $10 \%$ of these survived $4 \mathrm{mo}$. In contrast, on bare rock with no Chondrus $>85 \%$ of fucoid recruits grew to visible size and $65 \%$ of these survived 4 mo. Chondrus may have directly induced Fucus evanescens recruit mortality. Although allelopathic effects (Fletcher 1975) cannot be ruled out, epidermal surface 'sloughing' has already been reported for many crustose algae (Johnson \& Mann 1986) and also for Chondrus (Sieburth \& Tootle 1981). Furthermore, high (>50\% in untreated controls) mortality of $F$ evanescens recruits may be expected due to settlement on calcareous debris that is trapped under the turf. This represents a preferred but highly unstable substratum for Fucus zygotes.

In subtidal habitats, algal turfs may also have strong negative effects on canopy species recruitment. Coralline and fleshy red algal turfs effectively suppressed kelp (several species) recruitment in southern California (Dayton et al. 1984). Also, after removal of abundant red algal turf (mostly Phyllophora truncata), a 10 -fold enhancement of visible sporophyte density of Laminaria longicruis and L. digitata occurred (Chapman 1984). Like Chondrus, P. truncata is slow growing, but may outcompete very fast growing Laminaria plants by recruitment inhibition. This might be a general evolutionary strategy of turf-forming species, in contrast to large canopy-forming species. Moreover Chondrus and possibly many turf-and crust-forming alga are resistant to physical disturbance (Littler \& Littler 1980) and grazing (Lubchenco 1978, Norton et al. 1990, Parker \& Chapman 1994, Worm 1996). These traits may be involved in general trade-offs with growth rates (Littler \& Littler 1980) but not with competitive ability.

Acknowledgements. We are especially grateful to Heather Hunt and Fred Watts for helping us in the field, and to Peter Petraitis for statıstical advice. Funding for B.W. was provided by a scholarship from the International Council for Canadian Studies. Other costs were defrayed by grant A6497 to A.R.O.C. from the Natural Sciences and Engineering Council of Canada.

\section{LITERATURE CITED}

Benedetti-Cecchi L, Cinelli F (1992) Effects of canopy cover, herbivores and substratum type on patterns of Cystoseira spp. settlement and recruitment in littoral rockpools. Mar Ecol Prog Ser 90:183-191

Brawley SH, Johnson LE (1991) Survival of fucoid embryos in the intertidal zone depends upon developmental stage and microhabitat. J Phycol 27:179-186

Chapman ARO (1984) Reproduction, recruitment and mortality in two species of Laminaria in Southwest Nova Scotia. J Exp Mar Biol Ecol 78:99-109

Connell JH (1990). Apparent versus 'real' competition in plants. In: Grace JB, Tilman D (eds) Perspectives on plant competition. Academic Press, San Diego, p 9-26

Dayton PK, Currie V, Gerrodette T, Keller BD, Rosenthal R, Van Tresca D (1984) Patch dynamics and stability of some California kelp communities. Ecol Monogr 54:253-289

Dudgeon SR, Davison IR, Vadas RL (1989) Effect of freezing on photosynthesis of intertidal macroalgae: relative tolerance of Chondrus crispus and Mastocarpus stellatus (Rhodophyta). Mar Biol 101:107-114

Dudgeon SR, Davison IR, Vadas RL (1990) Freezing tolerance in the intertidal red algae Chondrus crispus and Mastocarpus stellatus: relative importance of acclimation and adaptation. Mar Bıl 106:427-436

Fletcher RL (1975) Heteroantagonism observed in mixed algal cultures. Nature 253:534-535

Green JE (1983) Factors controlling the vertical zonation of two intertidal seaweeds: Chondrus crispus Stackhouse and Gigartina stellata (Stackhouse) Batters. MSc thesis, 
Northeastern University, Boston

Johnson CR, Mann KH (1986) The crustose coralline alga, Phymatolithon Foslie, inhibits the overgrowth of seaweeds without relying on herbivores. J Exp Mar Biol Ecol 96:127-146

Littler MM, Littler DS (1980) The evolution of thallus form and survival strategies in benthic marine macroalgae: field and laboratory tests of a functional form model. Am Nat $116: 25-44$

Lubchenco J (1978) Plant species diversity in a marine intertidal community: importance of herbivore food preference and algal competıtuve abulities. Am Nat 112:23-39

Lubchenco J (1980) Algal zonation in the New England rocky intertidal community: an experimental analysis. Ecology 61:333-344

Lubchenco J, Menge BA. (1978) Communty development and persistence in a low rocky intertidal zone. Ecol Monogr 48:67-94

Mathieson AC, Burns RL (1971) Ecological studies of economic red algae. I. Photosynthesis and respiration of Chondrus crispus Stackhouse and Gigartina stellata (Stackhouse) Batters. J Exp Mar Biol Ecol 7:197-206

This note was presented by G. C. Harding, Dartmouth, Nova Scotia, Canada
Norton TA, Hawkins SJ, Manley NL, Williams GA, Watson DC (1990) Scraping a living: a review of littorinid grazing. Hydrobiologia 193:117-138

Parker T, Chapman ARO (1994) Separating the grazing effects of periwinkles and amphipods on a seaweed community dominated by Fucus distichus. Ophelia 39:75-91

Parker T. Johnson C, Chapman ARO (1993) Gammarid amphipods and littorined snails have significant but different effects on algal succession in littoral fringe tidepools. Ophelia 38:69-88

Sieburth JM, Tootle JL (1981) Seasonality of microbial fouling on Ascophyllum nodosum (L.) Lejol., Fucus vesiculosus L., Polysiphonla lanosa (L.) Tandy and Chondrus crispus Stackh. J Phycol 17:57-64

Stephenson TA. Stephenson A (1972) Life between tidemarks on rocky shores. WH Freeman, San Francisco

Thomas MLH. Page FH (1983) Grazing by the gastropod Lacuna vincta in the lower intertidal at Musquash head, New Brunswick, Canada. J Mar Biol Assoc UK 63:725-736

Worm B (1996) An experimental study on interactions structuring the lower rocky intertidal community in eastern Canada. Thesis, University of Kiel

Manuscript first received: March 12, 1996

Revised version accepted: November 11, 1996 